\title{
The Age of Revolution in the Indian Ocean, Bay of Bengal, and South China Sea: A Maritime Perspective
}

\author{
CLARE ANDERSON \\ School of Historical Studies, University of Leicester \\ 3-5 Salisbury Road, Leicester LEI $7 Q R, U K$
}

E-mail: ca26@le.ac.uk

\begin{abstract}
This essay explores the history of empire and rebellion from a seaborne perspective, through a focus on convict-ship mutiny in the Indian Ocean. It will show that the age of revolution did not necessarily spread outward from Europe and North America into colonies and empires, but rather complex sets of interconnected phenomena circulated regionally and globally in all directions. Convict transportation and mutiny formed a circuit that connected together imperial expansion and native resistance. As unfree labour, convicts might be positioned in global histories of the Industrial Revolution. And, as mutinous or insurgent colonial subjects, they bring together the history of peasant unrest and rebellion in south Asia with piracy in south-east Asia and the Pearl River delta. A subaltern history of convict transportation in the Indian Ocean thus has much to offer for an understanding of the maritime dimensions of the age of revolution.
\end{abstract}

\section{INTRODUCTION}

Two oceans away from revolutionary ferment in North America and Europe, maritime unrest in the Indian Ocean, Bay of Bengal, and South China Sea forms a critical part of the larger story of the great age of revolution. If we know, pace Eric Hobsbawm, that in the first half of the nineteenth century the French Revolution and the Industrial Revolution were the great motors (or, as he prefers it, midwives) of history, we also understand, pace Peter Linebaugh and Marcus Rediker, the importance of the American Revolution and proletarian radicalism in both connecting together and challenging the spread of industrial spaces of production across the Atlantic world. As they put it, the great irony of this important global process was that European expansion overseas itself created the conditions for the circulation of experience and resistance among the huge 
masses of labour that it set in motion. ${ }^{\mathrm{I}}$ Further, as recent work by David Armitage and Sanjay Subrahmanyam has shown, the age of revolution did not necessarily spread outward from Europe and North America into colonies and empires, but rather complex sets of interconnected phenomena - ideas about sovereignty, rights, and independence, as well as industrialization, revolt, and revolution - circulated in all directions. ${ }^{2}$ Their perspective enables historians to produce connections, comparisons, and patterns of causation that do not simply place the age of revolution in a more expansive, world history framework but, more radically, still allows us to rearticulate the relationship between the local and the global across multiple centres of change. ${ }^{3}$

To take the example of industrialization, economic productivity, and labour mobility, the Industrial Revolution was previously understood by historians as a specifically European revolution, but it is now clear that the English Lancashire mills made famous by Friedrich Engels were part of a complex economic chain of resource extraction and piece production that stretched from the plantations of the Americas to the factories and mills of Bombay and Calcutta, and to the port cities of Singapore and Canton. Historians have paid much attention to industrialization and "the great divergence" between Europe and China, to the great migrations associated with global shifts in the movement of capital and resources, and also to the importance of resistance and rebellion in challenging them. They have centred in their narrative land, labour, and statecraft; the enslavement and indenture of millions of Africans, Europeans, and Asians in European factories and plantations worldwide; and the global circulations of soldiers, sailors, merchants, and traders. Resources and commodities such as cotton, sugar, spices, tea, and tobacco are at the heart of this story, with the tiniest of threads, grains, nuts, seeds, powders, and leaves underpinning the largest of regional, imperial, and global histories.

This essay seeks to bring together Armitage and Subrahmanyam's ideas about the "multiple logics of transformation"4 with Linebaugh and Rediker's attention to maritime radicalism within the age of revolution. It will explore the history of empire, mobility, and rebellion from a seaborne

\footnotetext{
I. Peter Linebaugh and Marcus Rediker, The Many-Headed Hydra: Sailors, Slaves, Commoners, and the Hidden History of the Revolutionary Atlantic (Boston, MA, 2008), pp. I 50, I 52.

2. David Armitage and Sanjay Subrahmanyam (eds), The Age of Revolutions in Global Context, C.I $1760-1840$ (Basingstoke, 2009).

3. Miles Taylor demonstrates connections of other kinds, showing that Britain used its empire to ease political and fiscal pressures at home: through the transportation of rioters and rebels to penal colonies in Australia, and through drastic domestic retrenchment which was underpinned by the downscaling of imperial military forces. See Miles Taylor, "The i 848 Revolutions and the British Empire", Past and Present, I66 (2000), pp. I46-I80.

4. Armitage and Subrahmanyam, "Introduction", in idem (eds), The Age of Revolutions, p. xxix.
} 
perspective and, shifting our gaze beyond the revolutionary textures of Europe and North America, it will pay attention to the subaltern world of the Indian Ocean. I will take one strand of the complex web of imperialism, migration, labour, and resistance that underpinned the great political, ideological, and geographical shifts of the late eighteenth to midnineteenth centuries, and situate it within an expansive global framework. That thread is convict transportation, for it is one of the great paradoxes of the age that just as radical thinkers were working in the context of the radicalism of enslaved peoples to abolish the slave trade in the Atlantic world, the British East India Company busied itself simultaneously with the establishment of multi-directional flows of forced labour that cut across the seas of south, south-east, and east Asia.

Convict transportation brought together imperial understandings and desires regarding punishment and labour. The East India Company found it an attractive deterrent against crime because it believed that for cultural and religious reasons Asians especially feared it. But most importantly, the Company viewed it as a cheap and easy means of satisfying the labour demands associated with ongoing regional expansion into forts, port cities, littorals, and interiors. During the period I 787 to I 857 it shipped overseas some 30,000 convict workers, for which incipient Company settlements frequently competed. Subsequently, under the purview of the British Crown (which assumed control of India in I 858) three times as many convicts were sent to the Andamans penal colony. And yet these transportations have rarely featured in subaltern, maritime, or global history. This is curious, for convicts can be made to form a sort of circuit that connects together imperial expansion and native resistance. As unfree labour, convicts might be positioned in global histories of the Industrial Revolution. And, as mutinous or insurgent colonial subjects, they bring together peasant unrest and rebellion in south Asia with piracy in southeast Asia and the Pearl River delta and convict mutiny at sea. In both respects, convict transportation in the Indian Ocean has much to offer for an understanding of the maritime dimensions of the age of revolution most particularly as a global process characterized by what Armitage and Subrahmanyam call "empire-making and empire-breaking".s

\section{SUBALTERN CIRCUITS: CONVICTS AND COLONIALISM}

In south Asia, near-constant murmurings against East India Company land settlement and taxation regimes as well as outright peasant rebellion and resistance characterized the first half of the nineteenth century. The incursions of the East India Company were not so much characterized by 
a smooth implementation of Pax Britannica as constant warfare against a discontented countryside. ${ }^{6}$ In fact, if we bring together and place the European revolutions in a global context, the age of revolution itself can be argued to have lasted well beyond 1848 , and to have had a wide geographical reach. In the Bengal Presidency of India, for instance, tribal rebellions from the 1830 s were succeeded in 1857 by unrest across large swathes of northern India in what Europeans called the mutiny, or great uprising, and Indian nationalists later came to call the first war of independence against the British. These were land-based rebellions provoked by the East India Company's many economic, social, and cultural interventions into everyday life.

Across the Bay of Bengal, predating the establishment of European trading ports in the Pearl River delta and their invigoration and exploitation of the lucrative opium trade, vast networks of pirates preyed on the opium-carrying boats and junks of what historian Dian Murray has called the indistinct boundaries of water world. ${ }^{7}$ If European, North American, and Parsi (Indian) boats made it out of China, they faced further risks of piracy in the waters of the Straits of Malacca, the danger zone that stretched from Singapore to Penang and the tip of southern Burma, bordering the Andaman Sea. If the historical geography of peasant resistance in sub-continental south Asia was largely land-based, the coastlines, littorals, and inlets of south-east and east Asia lent it a distinctly maritime dimension. Of course both types predated the arrival of profit-seeking foreign traders, but even if unrest, rebellion, and piracy did not themselves intensify, the official response to their multi-pronged challenge to imperial interests certainly did. ${ }^{8}$

Though we usually think of imperialism as a process of territorial conquest effected across oceans, one way of connecting together nodes of colonization, rebellion, and resource extraction - and thus land, bay, and sea - is to consider the importance of the transportation of Asian convict challans $^{9}$ - their trans-port-ation - to fledgling British imperial settlements. These stretched from the south-east Asian littorals to military outposts and labour-hungry plantations. The port cities that knitted together this extensive penal network were part of a much larger global story of convict transportation. Law was used to criminalize individuals and communities, and to create new kinds of labour power. Ultimately this twin process created entirely new markets for free and unfree labour, for convicts were used to open up new areas for colonial expansion.

6. C.A. Bayly, Indian Society and the Making of the British Empire (Cambridge, 1988).

7. Dian Murray, Pirates of the South China Coast, I790-1810 (Stanford, CA, 1987).

8. Ibid.; John Carroll, Edge of Empires: Chinese Elites and British Colonials in Hong Kong (Cambridge, MA, 2005), ch. I.

9. Challans $=$ chain gangs, or batches of convicts. 
For our purposes, the British story began with the shipment of convicted felons from Britain and Ireland to the plantations of Virginia, Chesapeake, and the Caribbean in the seventeenth and eighteenth centuries. It continued with their closure as convict destinations in the aftermath of the American War of Independence and their replacement with transportation to Australia in 1787. And - in an important detail of history that is always missed in world history accounts that centre on Europe and North America - its scope was at the same time widened substantially through the setting up of intra-regional or south-south Asian convict flows. This began with the foundation of a penal settlement in Bencoolen in 1787 , two years before the French Revolution gave birth to the great shifts in economy and ideology that concern us here. It continued in the eighteenth century with transportation to Penang (I789-1857) and the Andaman Islands (I793-I796), and accelerated in the nineteenth century to encompass sites in Mauritius (I8 I 5-I 837), Malacca and Singapore (I825-I857), Arakan and Tenasserim in Burma (I828-I857), Aden (I84I-I849), and once again the Andamans (1858-1939). Collectively, these settlements received convicts from mainland south and south-east Asia, and the islands of Ceylon and Hong Kong - the latter of which also transported convicts to Van Diemen's Land and Sindh in western India. The East India Company shipped convicts outward to India too, with Chinese and Malay prisoners transported to the southern hill station of Ootacamund and the summer capital of the Bombay Presidency, Mahabaleshwar, during the mid-nineteenth century. Though the British Empire was reconstituted in the aftermath of the American Revolution, there were remarkable continuities over time with respect to the articulation and rearticulation of penal transportation - and its relationship to enslavement and indenture (European and Asian). ${ }^{\circ}$

The rationale for convict transportation in the south Asian context was deeply rooted in colonial concerns. The British believed that Hindus who journeyed across the black water, or kala pani, were outcaste, and so the authorities thought that transportation was a punishment worse than death. Certainly, caste was compromised when convicts of all classes and religions were chained and messed together. Many Indians had never before seen, let alone been to sea, rendering the ship an important tool of convicts' cultural and geographical displacement. In particular, normal practices regarding the preparation and eating of food, drinking, washing, and the performance of ablutions could not be respected. For high-caste or high-status convicts, this made the journey itself an important element of the punishment. ${ }^{\text {II }}$

I0. Clare Anderson, Subaltern Lives: Biographies of Colonialism in the Indian Ocean World, I790-I 920 (Cambridge, 20I 2).

I I. Idem, "The Politics of Convict Space: Indian Penal Settlements and the Andaman Islands", in Alison Bashford and Carolyn Strange (eds), Isolation: Places and Practices of Exclusion (London, 2003), pp. 4I-45. 
Likewise, the British in south-east Asia and Hong Kong believed that Malay and Chinese convicts especially feared transportation to unknown lands, because, having cut their family ties, after death they would not enjoy the burial rites necessary for their support in the afterlife. ${ }^{\mathrm{I}}$ For this reason, what the Colonial Secretary described as "distant and strange" destinations such as Sindh were chosen for Chinese convicts over the more geographically proximate and culturally familiar Straits Settlements or Tenasserim Provinces. ${ }^{\text {I3 }}$

Though the social impact of transportation made it an important element of the colonial penal repertoire across these Asian contexts, the East India Company also engaged convicts as a huge and seemingly unlimited workforce. In the ports, littorals, and interiors of islands and continents in the Indian Ocean, gangs laboured in occupations including jungle clearance; bund, bridge, and road building; infrastructural work; plantation agriculture; salt extraction; silk cultivation; prison manufacture; and tin mining. Thus, punishment and labour were brought together to remarkable effect. Convict work was said to be rehabilitative and reformative, but it also laid the infrastructural foundations for colonial settlement across the Indian Ocean and Bay of Bengal. Convicts enabled the expansion of trade, worked the land, and engaged in industrial production.

If convicts built and networked empire, convict transportation also created subaltern circuits of mobility, rebellion, and resistance. Some of the first Indian convicts transported to south-east Asia were Polygars from Malabar in South India, convicted in the wake of war against the East India Company at the turn of the nineteenth century. ${ }^{\mathrm{I}}{ }^{4}$ Convicts were also transported out of the Kol, Bhil, and Santal adivasi (tribal) communities, after they resisted colonial incursions into land and increasing revenue demands in the Bengal and Bombay presidencies during the period I830-1855. ${ }^{\mathrm{IS}}$

Pirates were sentenced to transportation in Hong Kong after it was ceded to the British Crown under the Treaty of Nanking (I84I). The British were

I 2. Christopher Munn, "The Transportation of Chinese Convicts from Hong Kong, I844-1858", Journal of the Canadian Historical Association, 8 (1997), pp. II3-I45, I22; India Office Records, British Library, London [hereafter IOR], $\mathrm{P} / \mathrm{I}_{4} 2 / 38$ Bengal Judicial Consultations [hereafter BJC], I October I 845 : J. Davis, Secretary to Government of Hong Kong, to Lord Stanley, 29 January I 845 . I3. IOR P/404/3 Bombay Judicial Consultations [hereafter BomJC], II August I846: W.A. Bruce, Colonial Secretary Hong Kong, to G.A. Bushby, Secretary to Government of India, 30 April I846; Bushby to Bruce, i I July I 846.

I4. Tamil Nadu State Archives, Chennai [hereafter TNSA], Madras Judicial Consultations vol. 98 (I 8 I 4): F.H. Baber, Magistrate North Malabar, to the Officer Commanding the Mysore Division, I I July i 8 I 4 .

I 5. Clare Anderson, Convicts in the Indian Ocean: Transportation from South Asia to Mauritius, I8I5-53 (Basingstoke, 2000), pp. 28-32. These early transportations anticipated the shipment to the Andamans from south Asia of 1857 rebels and mutineers, Wahabis, Manipuris, Kukas, Mapilahs, and nationalist agitators into the i920s. See N. Iqbal Singh, The Andaman Story (New Delhi, 1978), pp. 176-204. 
concerned about the island's apparent lawlessness as well the negative impact that the constant threat of piracy had on merchant vessels (and the opium trade) in what had become an important commercial port. There, and elsewhere in the South China Sea, they were especially fearful of maritime subcultures apparently beyond their control. They sought by turns both to criminalize piracy and to incorporate boat-dwellers into the colonial state. ${ }^{16}$ Unlike the radical analysis of piracy-as-Atlantic-socialprotest offered by Linebaugh and Rediker, it seems that piracy in the South China Sea was not so much revolutionary as entrepreneurial in character. ${ }^{17}$ But, though it is difficult to trace relationships between piracy and the anti-dynastic or proto-nationalism that characterized the age of revolution in Europe, North America, and the colonies, with traders and sailors from all over the world passing through east Asia's trading ports and with pirates transported as convicts into south and south-east Asian penal regimes, the region nevertheless became networked into new colonial spheres of productivity and resistance in unprecedented ways.

The layers of subaltern connection evident in links between colonial economic imperatives and transportation can be seen also in convict resistance on board ships and in penal settlements and colonies, most especially when convicts transported for "political" crimes later joined together in open mutiny. For instance, convicts who had been transported for "insurrection and bearing arms" when the princely state of Kolhapur was in a state of rebellion against the East India Company led a violent escape attempt in Aden $1845 .{ }^{18}$ And, when mutineers and rebels were shipped to the Andamans after the Great Indian Revolt of I 857 , numerous escape attempts were underpinned by subaltern beliefs that there was a sympathetic rajah living in the jungles of Great Andaman or that there was a high road connecting the islands to south-east Asia. Many convicts believed that they could find service with the "King of Burma" and return to the Andamans to destroy the penal colony. ${ }^{19}$ One mutinous sipabi [sepoy; soldier] later told British officials that he and other convicts thought that this man could be found after ten days' march into the jungles. ${ }^{20}$

16. Munn, "Transportation of Chinese Convicts", p. i I 5; Carroll, Edge of Empires, pp. 20-23. 17. As argued in Murray, Pirates of the South China Coast.

I 8. IOR P/403/47 BomJC, I 3 August i 845: Political Agent, Aden to W. Escombe, Secretary to Government of Bombay, 27 June I 845; Governor's minute, n.d. On the history of Kolhapur in the nineteenth century, see Imperial Gazetteer of India (Oxford, I908), XV, p. 383.

19. IOR P/206/6I India Judicial Proceedings [hereafter IJP], 29 July I859: Dr Browne's report on the sanitary state of the Andamans.

20. IOR P/206/6I IJP, 29 July I859: statement of convict no. 276 Doodnath Tewarry, 26 May I 859; M.V. Portman, A History of our Relations with the Andamanese (Calcutta, I899), I, pp. 279-286; IOR P/188/53 India Judicial Consultations, 7 May I858: Superintendent J.P. Walker to C. Beadon, Secretary to Government of India, 23 April I858; Beadon to Walker, 7 May I858; National Archives of India, New Delhi, Home Judicial Consultations, 28 May I858: Walker to Beadon, I May I858. 


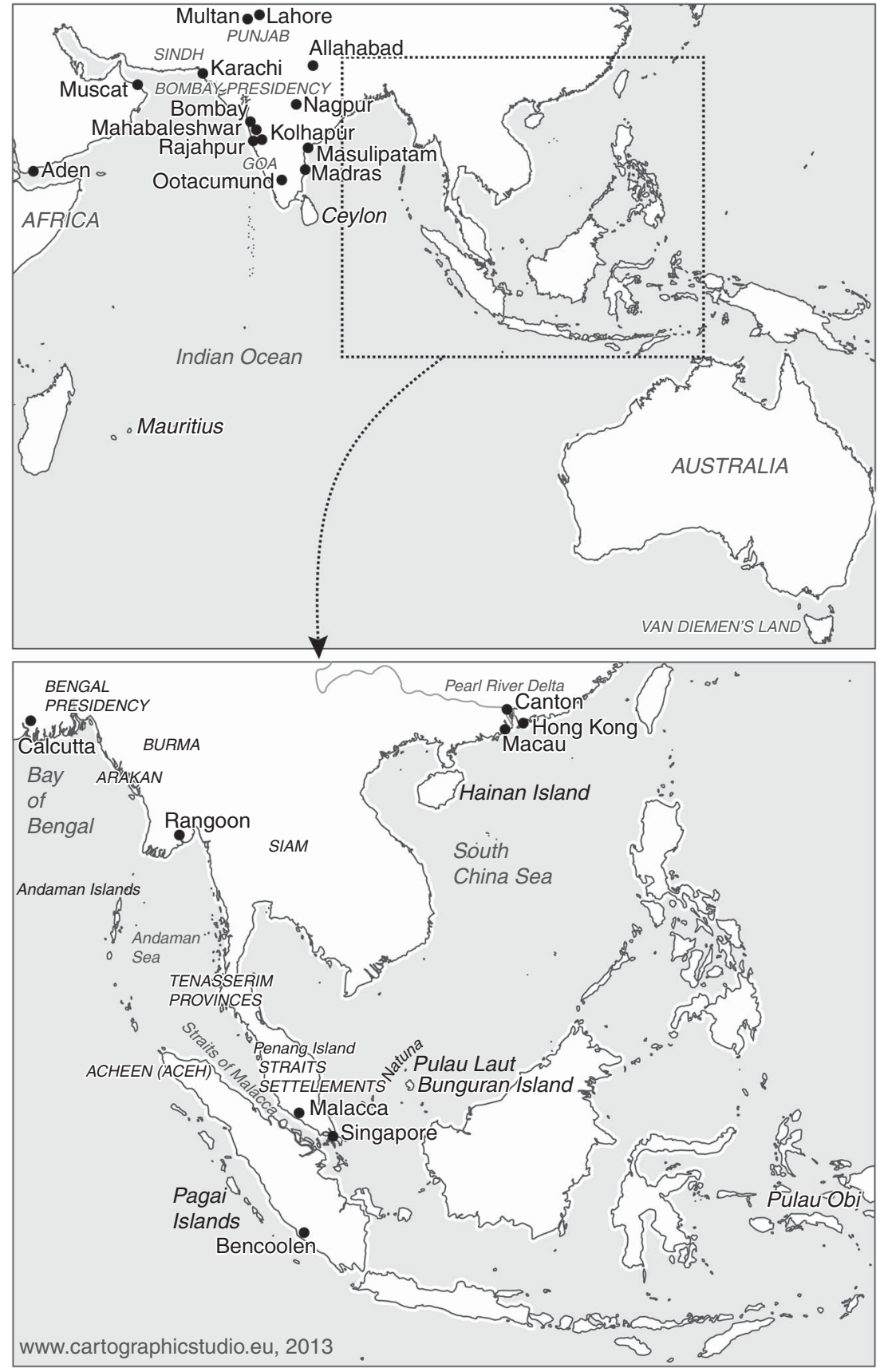

Figure I. Mutiny and Piracy in the Bay of Bengal and South China Sea. 
That penal transportation created networks and imagined geographies of anti-colonial resistance is evident in places like Aden and the midnineteenth-century Andamans. But the act of transportation itself - along rivers and across oceans - also supported the extension of terrestrial rebellion on to ships. Just like the merchant vessels of the Atlantic world described by Linebaugh and Rediker, convict ships were both engines of capitalism and spaces of resistance. They were especial conduits for the realization of colonial imperatives concerning punishment and labour as well as potential sites of violent anti-colonial struggle. Convict ship mutinies thus add a crucial maritime dimension to our understanding of subaltern resistance and unrest during this period, and offer a more expansive conceptual framework within which to trace both its character and its diffusion across land and sea around the Indian Ocean during the first half of the nineteenth century.

\section{CONVICTS AND PIRATES: MUTINY AT SEA}

Up to twenty convict ships left south and south-east Asian ports each year, carrying anything from a dozen to over 200 men - and occasionally one or two women. Until I 858 there were no ships specially fitted out for convicts. Rather, in the years before it lost its trading monopoly in I 834, the East India Company transported convicts on its China fleet, keeping them below decks under armed guard side by side with other cargo. Later, the Company put transportation out for tender, and henceforth convicts were carried overseas on private trading vessels. Arrangements became irregular and piecemeal, and though ships could not get insurance against uprisings they often kept costs down by skimping on armed guards. Convicts were accommodated between decks; if there was room they were kept in temporary prisons, otherwise these cargos of human capital slept next to bales of cotton, reels of silk, sacks of sugar, chests of opium, packs of dates, and sacks of betel nut. ${ }^{21}$ Convicts were allowed to come up for air for just two hours per day, and even then only if the weather was good. In squally conditions the state of the convicts' quarters deteriorated fast. As on boats carrying African slaves and Indian indentured labourers later on, "dancing masters" cracked whips to encourage exercise. ${ }^{22}$

It was during the period after I 834 that there was most convict unrest at sea - in total, during the period to 1858 there were two attempted mutinies, one upriver outbreak, and more than a dozen seaborne uprisings. This represented a very small proportion of transportation ships - far fewer

2 I. IOR P/I42/I6 BJC, 27 May I844: S. Garling, Resident Councillor Penang, to W.J. Butterworth, Governor of Straits Settlements, 28 February I 844 .

22. IOR P/403/6 BomJC, 2 March I 842: Court of Judicature, Penang, 7 June I 84I, testimony of Salamon. 
than the estimated Io per cent of Atlantic slave ships that mutinied. ${ }^{23}$ However, unlike the ships of the slave trade, convict transportation was regulated publicly, and so mutinies were subject to government enquiries. An extensive archive survives, and it opens up extraordinary insights into convict mutineers' motives and desires.

Convict mutinies were always opportunistic, and without exception they arose out of failures to properly inspect, accommodate, or guard convicts. ${ }^{24}$ Convicts were able to smuggle on to ships knives, small files, iron nails, and emery boards, sewn into the folds and ends of their bedding. ${ }^{25}$ Their irons were frequently lightweight or rusted. Crews allowed them above decks in large numbers, or left muskets loaded or unsecured. ${ }^{26}$ Furthermore, men were commonly locked on a single chain padlocked at one end only. If one man was released, the remaining convicts could slip out. ${ }^{27}$ Convicts were ingenious in the use of waxed silk thread to cut through their fetters, stuffing the breaches with cement made from wax and dye so that they could not be detected. ${ }^{28}$ Men also took advantage of any unsecured convict women on board, to obtain information in planning outbreaks about the ship's routine, the location of arms, and other matters. ${ }^{29}$

Further, mutiny rarely broke out on vessels unless they were carrying convicts who had been soldiers, sailors, or pirates - for the simple reason that those convicts knew how to use weapons or had previously been to sea, and so possessed the skills necessary to take a ship. That is why mutinies overwhelmingly occurred on vessels sailing out of Bombay, the Straits Settlements, and Hong Kong, rather than Bengal or Madras. The Ararat (Singapore to Bombay, I 859 ), for instance, embarked fifty-two pirates $;^{3 \circ}$ they secreted a knife on board, and used it to cut themselves free.

23. Stephen D. Behrendt, David Eltis, and David Richardson, "The Costs of Coercion: African Agency in the Pre-modern Atlantic World", Economic History Review, 54 (200I), pp. 454-476. 24. David Richardson, "Shipboard Revolts, African Authority, and the Atlantic Slave Trade", William and Mary Quarterly, 58 (200I), pp. 69-92, 75.

25. Bengal Hurkaru, is September I 859 ; IOR P/I45/32 BJC, I 4 February i 856: H. Fergusson, Superintendent Alipur Jail, to A.W. Russell, Under Secretary to Government of Bengal, 24 January I 856.

26. IOR P/402/39 BomJC, 3i December I 839: P.W. Le Geyt, Acting Senior Magistrate Police Bombay, to J.P. Willoughby, Secretary to Government of Bombay, 24 December I 839; P/402/2 BomJC, 24 June I846: Willoughby's minute, 9 June I846; P/404/3 BomJC, 6 August I846: W.F. Curtis, Superintendent Convicts Bombay, to Escombe, I 8 July i 846 ; IOR P/I43/5 I BJC, 3 I July i 850 : E.H. Lushington, Magistrate Patna, to J.P. Grant, Secretary to Government of Bengal, 23 June 1850.

27. IOR P/I43/5 I BJC, 3 I July i 850 : Capt. H.M. Nation, Commanding Behar Station Guards, to J.W. Dalrymple, Under Secretary to Government of Bengal, 25 June I 850.

28. IOR P/145/32 BJC, I4 February i 856 : Fergusson to Russell, 24 January i 856.

29. IOR P/402/30 BJC, 30 January I 839 : information of Captain F.N. Pendygrass (Catherine), I9 January I 839 .

30. Bengal Hurkaru, i4 September 1859 . 
There followed an extraordinarily bloody uprising. The crew largely escaped injury, but before it resumed control of the ship thirty-five of the seventy-four convicts had either been shot dead or had jumped overboard and drowned. ${ }^{3 \mathrm{I}}$

Eight of the sixteen convict mutineers on board the Harriet Scott (Penang to Bombay, I 843) were convicted pirates. Each had been doubly ironed, and chained together, but a rusty shackle proved the ship's downfall. The convicts freed themselves, armed themselves with pikes, and locked the crew below deck. They killed Captain Philip Benyon and cut his body into pieces. They got into the quarter boat, lowered it down, and escaped from the ship. The chief mate, who had himself sustained a serious head injury, took revenge on a convict who had not been involved in the uprising, shooting him dead and killing others who had been badly injured. ${ }^{32}$ The escaped men were found exhausted and hungry by another vessel. They were given food, and confessed that they were escaped convicts. They were promised a free passage if they remained quiet, but instead were taken to Penang and handed over to the authorities. ${ }^{33}$ They were tried and sentenced to hang, and were said to have mounted the scaffold "with great firmness". Their bodies were cut down and taken to the pauper hospital for dissection. Subsequently, the government urged ships to check that convicts had nothing in their possession with which they could cut their fetters, and to examine their irons twice a day. ${ }^{34}$

Hong Kong convicts gained an especial reputation for violent disorder. The General Wood (Hong Kong to Penang, via Singapore, I 848) carried ninety-two convicted pirates on board - most from Hong Kong, but also including one "notorious Macau Portuguese". The day after the ship sailed out of Singapore harbour on the final leg of its journey to the island of Penang, there was what was later described as an uproar. The convicts seized the ship's firearms, threw fifty lascars (sailors) overboard, killed Captain William Stokoe and the three mates, and left just three Europeans alive: the newly wed Lieutenant and Mrs L.W. Seymour, and a passenger called Andrew Farquhar. They made plain that had Mrs Seymour been the wife of Deputy Police Superintendent Caldwell at Hong Kong, they would have "chopped her into pieces". For thirteen days the convicts

31. Ibid., is September 1859 .

32. IOR P/I42/8 BJC, I 3 November I 843 : Butterworth to A. Turnbull, Under Secretary to Government of Bengal, 7 October I843; IOR P/I42/9 BJC, 27 November I843: Garling to Butterworth, 25 September I 843, enc. deposition of Thomas Jones, second mate of the Harriet Scott, n.d.

33. IOR P/I42/8 BJC, 27 November I 843: deposition of Sheck Hyder Aly, a passenger on the Brig Harsingar, n.d.

34. IOR P/I42/is BJC, 29 April I 844 : memorandum for the information of commanders of vessels engaged for the conveyance of convicts, 29 February I844; Penang Gazette, I6 December I843. 
steered for Pulau Laut, a small island in the Natuna archipelago of the South China Sea. When they arrived, they lowered the boats to shore, leaving ten men behind to kill the remaining lascars and blow up the ship. Hearing of their arrival, some local Malays came to meet the party, and while the convicts were distracted they managed to spirit away Lieutenant and Mrs Seymour and Mr Farquhar, saving their lives. They dispatched a note to the "rajah" Orang Kaya (described as "principal chieftain" of the Natunas) who lived on the island of Bunguran.

I take up the story in the words of his deputy, Datoo Buntara:

On that night at 2 o'clock, two men in a small Boat arrived with a letter to me. I read it, it mentioned that ship wrecked men had landed at Pulo Si Lout; Europeans three, 2 males and I female; Lascars, and a very great number of Chinese who wanted to have killed the Europeans, but we have rescued and run away with them up the Hill. We are now much afraid that if Dattoo does not come to our assistance we will be in trouble to night. I immediately wrote to the Orang Kaya at Pulo Lemadang requesting him to bring Prows armed to Pulo Si Lout as our men there were in danger. After which I assembled all the men and desired them to prepare and arm themselves [...]. In a short time say in $1 / 4$ of an hour they were ready I4 Prows with 400 men and we proceeded to Pulo Si Lout - at 6 o'clock I arrived the men told me the Chinese had left during the night leaving $1 / 2$ their number behind, also I Portuguese, in all 19 men - I then ordered the Prows to go in search of the runaways amongst the neighbouring Islands [...]. The Chinese on shore were watched. I then went on the Hill to see the Europeans and found 2 Gentlemen and a Lady - I enquired how this had occurred, they replied that the Chinese convicts had seized the ship and murdered the Captain, Mate and others. I told them to remain where they were as I intended to go after the escaped Chinese - on going I found a broken boat drifting. Some of the men in the other Prows found 4 Lascars in a small boat who informed me that the ship had gone down. The boats returned after a fruitless search [...]. After being on the Island one week a convict hung himself consequently I ordered the others to be handcuffed and watched. I afterwards spoke to the Orang Kaya about sending them all to Singapore [...]. After a stay of 2 weeks we departed touching at Pulo Dadap for wood and water and were there detained from stress of weather for one week during which time all our provisions were consumed and we were compelled to return for a fresh stock. We then sailed again and in 5 days reached Pulo Punoo sooh where we were overtaken by a storm when a convict in the bustle and confusion jumped overboard - the next morning we reached the Harbour. Mr Andrew Farquhar landed, then Mr George came on board to land Mr and Mrs Seymour after which the Constables and Peons came and took the convicts and Lascars on shore.

The British subsequently gifted the Orang a substantial Spanish \$300 cash reward, half a dozen flint muskets, a six-pounder gun bearing what was described as a "suitable inscription", and - at his request - a "document to show his neighbours and commanders of vessels". To the "gallant Malays" who protected the Europeans were given money, rifles, and muskets. 
Twenty-eight other convicts were later recaptured further south on Pulau Obi, and they told British officers that the remainder had left for Siam, Singapore, or Hainan Island off the coast of southern China. ${ }^{35}$ The Pulau Obi convicts had in their possession various articles that they had plundered from the General Wood, some clearly useful equipment, and some of potential sale value. They were: a two-day chronometer manufactured by Koskell of Liverpool; a ship's timepiece; a Chinese lacquer box containing opium; an ivory card case that contained a paper written by Mrs Seymour; a pocket compass; a London-made telescope; a silver watch case; and a silver table fork and a silver salt spoon, presumably the property of the Seymours for they were marked with the initials "W\&MS" and "WS" respectively.

Found on the person of one of the men was a piece of "Chinese writing", which was translated as follows:

If any of us should die, the death of such person is to be made known to the survivors.

If any of us should succeed in procuring a boat the same is to be made known to all of us.

None of us are to leave the Island [Pulau Obi] until we have fed and lived well so as not to be recognized as convicts when we get to China.

When I go to China, no one save God will know who I am.

We are to share alike in every thing, if we procure food we are to share alike.

If one of us procure[s] a boat the same is to be made known to all of us, that we may go together.

We all swear to assist and stand by one another to the last.

God only besides ourselves shall know our actions and what is in our possession. ${ }^{36}$

The paper was not signed. In the Atlantic world, such "round robins" were a common feature of piratical seizures. They captured what Rediker has elsewhere described as the "collective logic" behind mutiny, for they were used to organize uprisings without revealing individual identities to the authorities. ${ }^{37}$ That the same tactic was used in the inlets and islands of

35. IOR P/I43/2 I BJC, I 2 July i 848 : Butterworth to A.R. Young, Under Secretary to Government of Bengal, 6 March I 848; statement of Lieutenant L.W. Seymour, n.d., Butterworth to Dalrymple, 6 May i 848; "memorandum of mine Datoo Buntara Yayah regarding the ship wrecked men within the limits of Pulo Bungoran", n.d.; Straits Times Extra, 20 February I 848; Bengal Hurkaru, 25 March I848. The case of the General Wood fed into a growing ambivalence in Singapore about the continued transportation of Chinese convicts to a by now flourishing colonial settlement. See C.M. Turnbull, "Convicts in the Straits Settlements 1826-1867", Journal of the Malaysian Branch of the Royal Asiatic Society, 43 (1970), pp. 97-103, 88-89. 36. IOR P/I $43 / 2$ I BJC, I 2 July i 848 : list of articles found on different parts of Pulo Oly [Ubin] in possession of the Chinese now prisoners; translation of a Chinese writing found on the person of a Chinese convict at Pulo Oly [Ubin], n.d.

37. Marcus Rediker, Between the Devil and the Deep Blue Sea: Merchant Seamen, Pirates and the Anglo-American Maritime World, 1700-1750 (Cambridge, 1987), pp. 234-235. 
east and south-east Asia reveals something remarkable about an apparently borderless maritime world of mutual codes of honour. That said, once the pirates had been captured, one of the men turned on the others, pointing out two individuals who he claimed had killed Captain Stokoe. They jumped overboard as they sailed from Pulau Obi to Singapore; one man was picked up, but the other drowned. ${ }^{38}$

As for Indian transportation ships, two of the thirty-four Virginia convicts (Bombay to Singapore, I 839 ) $^{39}$ had been professional sailors one a caffree and the other a sydee (both words implying African in maritime parlance).$^{40}$ They escaped the ship and made for the shore just south of Goa; some headed for their home villages, and others travelled towards the eastern Indian port of Masulipatam, with the intention of taking a ship to Muscat. But the men were recaptured, at the time complaining that they had mutinied because they had been short rationed, and otherwise "starved and ill-treated". ${ }^{\text {I }}$ The Virginia convicts were re-embarked on the Freak (Bombay to Singapore, I 84I), and, incredibly, they again broke out in mutiny. This time they succeeded in murdering the captain and chief mate. They took control of the vessel, stopping on the Pagai Islands close to Bencoolen, in the mistaken belief that they were the Nicobars; they then steered up the coast of Sumatra, and eventually landed at Acheen. They said they were traders with opium, cotton, dates, and piece goods to sell. The Rajah heard rumours of the arrival of a batch of convict mutineers, came to shore, and inspected the ship. The convicts presented him with a chronometer, the captain's watch, sword, and gun, and upon learning of events he personally enlisted fourteen of the mutineers as sepoys in his service, including the man who had been implicated in the murder of Captain Whiffen of the Virginia. ${ }^{42}$

At least one of the convicts shipped on the Catherine (Bombay to Singapore, 1838 ) had previously worked as a lascar. That ship was carrying sixty men, almost double the number it was certified to take. The captain became aware that the convicts were planning to take the ship, and so returned to Bombay. Re-embarked with a strengthened guard, when it finally landed in Singapore the senior police magistrate of the port

38. IOR P/I43/2 I BJC, I2 July i 848: Captain George Nibbett, Commander Phlegathon, to Captain P. McQuhae, Senior Officer Straits Settlements, n.d., enc. "Names of the convicts captured on Pulo Oly [Ubin] by the HCSV Phlegathon as given by themselves".

39. IOR P/402/39 BomJC, 3I December I 839: Le Geyt to Willoughby, 24 December I 839.

40. IOR P/402/39 BomJC, 3 I December I 839: deposition of seacunnie [steersman] Charles de Cruz, n.d., minute of Governor J.R. Carnac, 28 December I839; IOR P/402/43 BomJC, I I March I 840: Willoughby's summary, 27 February I 840.

41. Bombay Gazette, 20 July i840. See also IOR P/402/39 BomJC, 3I December I839: deposition of seacunnie Charles de Cruz.

42. IOR P/403/6 BomJC, 2 March I842: Court of Judicature, Penang, 7 June 1841; Penang Gazette, I0 April r84I; Bombay Gazette, 22 May I84I, 9 June I84I; The Times, 6 September I84I. 
wrote that the smell below deck was so disgusting that he could not find words to describe it. He discovered several of the convicts sick with venereal and other diseases, and opined there had been no medical attendant on board. ${ }^{43} \mathrm{~A}$ further dimension to the conviction of sailors and pirates was that shorthanded captains on occasion employed them as crew. Sheikh Ramran, a sipabi guard on the mutinous Clarissa (Bengal to Penang, I 854), claimed that the captain had even placed a convict in charge of his swords and muskets, which as we will see was a fatal miscalculation on his part. ${ }^{44}$

But there was a more radical dimension to convict mutiny than some of these cases might suggest, for it was sometimes expressive of subaltern desires for freedom, not solely from transportation or carceral restraint, but from colonial domination more generally. As such, maritime radicalism in the Indian Ocean drew on wider-ranging socio-political, and anti-colonial grievances that characterized the age of revolution within the more expansive global framework that I am proposing here. In this respect, it is important to note that there were significant connections between the land-based rebellions for which Indian convicts were transported and subsequent outbreaks at sea. Convicted rebels sometimes carefully planned mutinies, often while they were still in jail awaiting their embarkation overseas. ${ }^{45}$

Two of the convict leaders on board the Catherine, for example, were bhils who were transported in the context of bhil campaigns against British territorial expansion into the forests of western India during the I830s. They planned the uprising before the ship had even left port, deciding upon the morning after Christmas when "the Captain and Officers would make themselves merry [and] they could have a better opportunity". A "conjuring book" pointed to $3 \mathrm{am}$ as the best time. It further advised them to divide themselves up, avoid Portuguese Goa, and head for "Chitripoore Ram Rajah's country [...] Rajahpoor" - presumably the established Hindu Saraswat Brahmin community in Kannada - for protection. They would "eat and drink and live there as nobody would be there to molest them". ${ }^{46}$ Likewise, a dozen of the seventy-nine convicts shipped on the Recovery (Bombay to Singapore, I 846) were marattas,

43. IOR P/402/30 BomJC, 23 January I839: depositions of Captain F.N. Pendygrass, I 2, I9 January I 839 .

44. IOR P/I45/I 8 BJC, I3 September i 855: deposition of Sheikh Ramran, son of Russub Alla, sepoy Alipur Militia, I 7 June I 8 54. For corroboration see also the deposition of Hwikh Joomur, son of Sheikh Talib, sepoy Alipur Militia, I7 June I854.

45. IOR P/402/30 BomJC, 30 January I839: deposition of Pendygrass, I9 January I 839 ; J.A. Forbes, Acting Senior Magistrate Police, to Willoughby, 22 January i 839.

46. IOR P/402/30 BomJC, 23 January I 839: depositions of Sahola Fuzul, Rama Balloo, and Juttoo Bin Mahomed Adky, 25 December I838. On bhil resistance, see Ajay Skaria, Hybrid Histories: Forests, Frontiers and Wildness in Western India (New Delhi, I999), p. 42. 
convicted and transported for insurrection, rebellion, or treason in the districts of the Bombay Presidency. It was these men who wrote a mutiny plan in jail, and then after they left port broke out of the holds, overpowered the sentries and guards, and got up on deck - though the crew managed to force them into retreat, killing one man and wounding five. ${ }^{47}$

More dramatically, in the aftermath of the Anglo-Sikh Wars of the I 840 s, Punjabi convicts became notorious for their violent resistance to British control. In 1850 , a challan of Punjabis travelling up river from Allahabad to Calcutta for transportation to Burma seized a steamer called the Kaleegunga. They had been locked on a single chain, padlocked at one end. When two men were let off to answer calls of nature, the remaining convicts escaped. ${ }^{48}$ Eighteen loaded guns had been stored within arm's reach of their sleeping quarters; they grabbed them, killed three guards, and jumped off the boat to shore. Their leader was described as a "notorious Sikh general", Narain Singh, who had been convicted of treason in the aftermath of Britain's annexation of the Punjab in I $849 .{ }^{49}$

Another mutiny, on the Clarissa in 1854 , was an uprising of unprecedented scale, and underlines especially well the connections that can be drawn between radicalism on land, mutiny at sea, and anti-British military campaigns. The bulk of the $\mathrm{I} 33$ convicts on board were Punjabis; they mutinied, murdered Captain Johnson, the chief and second mates, and half the crew and guard (3 I men), and escaped. ${ }^{\circ}$ One convict claimed that during the uprising leader Soor Singh had called out: "The Ferringees [foreigners] are flying - the ship is ours!"sI Earlier the convicts had complained about the overcrowding and heat below decks, ${ }^{52}$ but the mutiny had been sparked when one man complained about his water ration, and struck the sipabi guard on the head with his brass lotab [drinking vessel]. ${ }^{53}$ One convict put it like this: "In the ship we all got cheated out of our provisions. Short measure and not enough water.

47. IOR P/403/55 BomJC, 4 February I 846 : list of convicts under sentence of transportation to Singapore, n.d.; IOR P/404/2 BomJC, 24 June I 846: Captain J. Johnson to J. Church, Resident Councillor Singapore, is April i 846, enc. "Names of those killed and wounded on board the Recovery on the 5 th February in a revolt of the convicts".

48. IOR P/I43/5 I BJC, 3 I July i 850 : Nation to Dalrymple, 25 June I 850.

49. IOR P/I43/5 I BJC, 23 June I 850 : Lushington to Grant, 23 June I 850 . For a detailed biography of Narain Singh, see Anderson, Subaltern Lives, ch. 4.

50. IOR P/I45/I 8 BJC, I3 September I 855 : S.R. Tickell, Principal Assistant Commissioner and District Magistrate Amherst, to W. Grey, Secretary to Government of Bengal, enc. matter of the Queen v. the life convicts on board the Clarissa for affray attended with homicide and for murder on the high seas, I4 July I 854 .

5I. IOR P/145/18 BJC, I3 September I855: deposition of Shaik Sooiah, son of Chambale, convict no. 72,30 June 1854 .

52. IOR P/I45/I8 BJC, I3 September I855: deposition of Goolab, I4 June I 854.

53. IOR P/I 44/6 I BJC, I 5 June I854: deposition of Sheikh Suvraj, son of Sheikh Kitaboodeen aged 30 - burra tindal [boatswain's chief mate] of the Clarissa, I9 May i 854 . 
All men discontented and began to be alarmed at our fate." ${ }^{4}$ Having taken the vessel, the convicts destroyed the convict register and logbook, ran the ship aground, armed themselves, and waded to the southern Burmese shore. 55

But this was no simple protest about shipboard conditions. Leader Soor Singh took charge, putting on the captain's coat and boots, and the gold necklace, sword, and sash belonging to the subadar (head) of the guard. $\mathrm{He}$ armed six other convicts, gave them "caps and accoutrements", and called them "his sepoys". ${ }^{6}$ Another central figure in the mutiny was Kurrim Singh (who later turned informer), who had previously been an artilleryman in the fifth company at Rangoon, and understood a little Burmese. ${ }^{77} \mathrm{He}$ described how the convicts were assembled on the beach, Soor Singh sitting before them in a chair. ${ }^{58} \mathrm{He}$ told them: "you shall be taken to the Burma Raja's and there be all free men". 59 Thinking that they were in lands as yet uncolonized by the British, the seven leaders made their way to his district, planning to offer him their services in anti-British campaigns. But they were mistaken, for the East India Company had annexed Lower Burma following the Second Anglo-Burmese War (I 852 ). They found the Rajah, but a gunfight broke out, and Soor Singh and his six men were killed. ${ }^{60}$

The surviving convicts (I 29 in number) were captured and brought before the Burmese magistrate for an initial hearing. Ill-equipped to cope with even this stage of such a complex case, ${ }^{61}$ he sent them back to Bengal, where they were put to trial in Calcutta's supreme court. ${ }^{62}$ The chief judge, Sir J. Colville, stated that it was the most serious trial that he had ever come across. ${ }^{63}$ Eighteen men were charged with the murder of the captain, three more with the murder of the subadar and bavildar (deputy) guard, and one with shooting a lascar after he jumped overboard. All faced trial for piratical seizure of the vessel, their offence in law.

54. IOR P/145/18 BJC, I3 September I855: deposition of Boor Singh, son of Humeer Singh, convict no. II 5,6 July i 854 .

55. IOR P/I44/6r BJC, is June I854: Tickell to A. Bogle, Commissioner Tenasserim Provinces, I8 May I 854; Bengal Hurkaru, 6 July i 854 .

56. Many of the witnesses testified to this military display. For example: IOR P/I45/1 8 BJC, I3 September I855: deposition of edoo serang [boatswain], I3 June I 854.

57. Bengal Hurkaru, I6 August I 854 .

58. IOR P/I45/I8 BJC, I3 September I855: deposition of Sheikh Suvraj.

59. IOR P/I45/18 BJC, I3 September I 855 : deposition of Beejah Sing, son of Punchum Sing, convict no. 5, 2 I June I 854 .

60. IOR P/145/1 8 BJC, I3 September I 855 : deposition of Kurrim Singh, son of Hennath Singh, convict no. I, 8 June I 854 .

6r. IOR P/I45/I8 BJC, I3 September I 855 : Tickell to Grey, I4 July I 854 .

62. IOR P/I44/6I BJC, Is June I 854 : Advocate General C.R. Prinsep's opinion, 9 June I 854. 63. Bengal Hurkaru, I2 August I854. For further reports of the Supreme Court trial, see Bengal Hurkaru, I4, I6-19 August I854. 
Assah Singh deposed: "I came all the way from Lahore to Calcutta a thousand coss if I had wishes to rebel outbreak from confinement could I not have done so more easily during that long journey on land than at sea?" $64 \mathrm{He}$ was one of four convicts sentenced to death, and when the sentence was read out it was said that he gave a "sneering contemptuous laugh which made one shudder" ${ }^{65}$ The remainder of the convicts were transported as per their original sentence. They were not allowed to progress through the penal classes, like other convicts in the Straits Settlements. Instead it was directed that they were to be kept at hard labour during their entire term. ${ }^{66}$

There were at least two outbreaks on convict ships in the aftermath of the Indian Revolt of I 857, through which previously land-based military and peasant resistance was carried overseas. In February i 858 forty-four convicts, including sepoys convicted of mutiny, were embarked on the Julia for Singapore, in the weeks before the announcement of the new penal colony in the Andamans. When the ship's carpenter entered the below-decks prison they took the chance to grab his tools, and kill and disarm the chief guard and his sentry. The ship's officers accessed the hatches, opened fire, and shot two convicts dead. They ordered the remainder up on deck, and chained them to the bower cable and anchor, where they left them in the shadow of the loaded forecastle gun. Three convicts died overnight. ${ }^{67}$ When the ship arrived in Singapore the authorities promptly ordered it on to the Andamans, without putting the convicts on trial for mutiny, perhaps fearing the spread of unrest. ${ }^{68}$ At the end of I 858 another thirty-seven rebels were sent from Multan to Karachi on the Frere, ready for shipment to the Andamans. Despite the fact they had previously tried to escape from jail, no special instructions were given to the ship's commander. They were able to slip their fetters off and rush the deck. Before the ship's command took control seven convicts had gone missing and two were dead. "Unless a prisoner is secured in a manner which humanity must forbid", the subsequent enquiry opined, "he cannot be kept in safe custody unless he is constantly watched". ${ }^{69}$

64. IOR P/I45/18 BJC, I3 September I855: deposition of Assah Singh, son of Chur Sing, convict no. 9I, 3 July I 854 . A coss is approximately one and a half miles.

65. Bengal Hurkaru, i9 August 1854 .

66. Ibid.

67. The Maitland Mercury and Hunter River General Advertiser, I7 August I 858 .

68. IOR P/407/i० BomJC, 6 July I 858: Beadon to C.J. Buckland, Junior Secretary to Government of Bengal, 24 April i 858; IOR P/407/13 BomJC, 21 September i 858: G.W. Blundell, Resident Councillor Penang, to G.W. Anderson, Governor of Bombay, Is June I 858; Singapore Free Press, 22 July I 858.

69. IOR P/407/30 Bombay Judicial Proceedings [hereafter BomJP] 4 July i 8 59: H.B.E. Frere, Commissioner Sindh, to Anderson, 4 June I859; G.W. Hamilton, Commissioner Multan, to Judicial Commissioner Panjab, 8 November i 858. 
There was an associated politico-religious dimension to some shipboard rebellions too. The convicts on the Recovery were said to have sworn on the Qur'an to mutiny before the ship had even set sail. Rumours reached the authorities that some "Arabic" vessels would be waiting in the harbour to help the convicts escape. When the ships did not appear, Captain Thomas Johnson dropped his guard, and it was then that the convicts rose. The signal for mutiny was "din", the cry of Koranic devotion and duty. ${ }^{70}$ A convict informer from the Freak claimed that after killing the captain and chief mate, one of the convicts had declared: "now all the poison all the liquor is coming out". He then threw the crews' shoes overboard, declaring them "infidels' things". ${ }^{71}$ The second mate added that the convicts had decided to go to Mecca, but, believing that they would get caught, decided to make for Aceh instead..$^{2}$ The leader, Hadjee Hussain, had asked the second mate whose country it was:

$[\mathrm{H}] \mathrm{e}$ said a Mohamedan country, the inhabitants are Malay. Hadjee Hussain asked if there are any English? [T] he $2^{\text {nd }}$ mate said "No" if the English go there they are killed and if an English vessel go there, all the men are killed and the ship plundered, Hadjee Hussain asked how large is the country $2^{\text {nd }}$ mate said I4 miles broad and 200 long. The Rajah and Troops reside there, and I 2 Governors in different parts, so Hadjee Hussain said "take the vessel there" and the ${ }^{\text {nd }}$ mate steered for Aceh. ${ }^{73}$

The second mate of the Freak, Francis Ward, stated later that the crew had been "very familiar with the convicts" and thought that they must have known of the convicts' intentions. His suspicions remained, however, entirely speculative. ${ }^{74}$

\section{JUSTICE AND RETRIBUTION AT SEA}

It is well known that maritime authority was violent and arbitrary, with British officers boasting that they were lords of the oceans. ${ }^{75}$ With respect to transportation, there were very real risks associated with carrying convicts, and land-based authorities often congratulated captains for floggings, beatings, or shootings during episodic unrest. In I $84 \mathrm{I}$, for example, convicts on the Singapore Packet complained about their rations and stormed the deck. The Governor of the Straits Settlements, S.G. Bonham, joined the local press in congratulating Captain Tingate for

70. IOR P/403/56 BomJC, i I March I 846: J. Geddes, Marshall Bombay County Jail, to W.F. Curtis, Superintendent of Convicts Bombay, I February I 846.

7I. IOR P/403/6 BomJC, 2 March I 842: deposition of convict Michael Anthony, 7 June I 84 I.

72. IOR P/403/6 BomJC, 2 March I 842 : deposition of second mate Francis Ward, 7 June I $84 \mathrm{I}$.

73. IOR P/403/6 BomJC, 2 March I 842: deposition of convict Michael Anthony.

74. IOR P/403/6 BomJC, 2 March I 842 : deposition of second mate Francis Ward.

75. Rediker, Between the Devil and the Deep Blue Sea, ch. 5 . 
his "bold and manly conduct" in quelling the outbreak, as a result of which four convicts had died. ${ }^{76}$ Attempted mutiny on board another Bombay ship, the Recovery, was suppressed with even more brutality. Captain Johnson gave every convict who had been on deck at the time three dozen lashes, and twenty others "as much as they could take". ${ }^{77}$ After a convict outbreak on the Ararat, Captain Correya stripped the survivors naked, and gave all of them, including twenty-eight men who had played no part in the mutiny, three or four dozen lashes. ${ }^{78}$

Here, we see tensions between governance at sea and on land, for while the Bengal Hurkaru congratulated Correya for his "courage and pluck" in staving off disaster, ${ }^{79}$ both the Secretary of State for India and the Madras authorities banned him from captaining convict ships in the future. ${ }^{80}$ The captain himself claimed that he had removed the convicts' clothing to make sure that none had hidden weapons, ${ }^{8 \mathrm{I}}$ but there is no doubt that the public removal of garments was also an emasculating punishment which was part of the armoury of colonial penal practice during the first half of the nineteenth century. ${ }^{82}$ The tensions between land and sea are illustrated also in the case of the Harriet Scott. At the time of the convict mutiny, chief mate John MacDuff was drunk, and in this state of intoxication he shot dead two convicts who had taken no part in the mutiny. Fearing what might happen next, the passengers and crew placed him in irons. ${ }^{83}$ The authorities arrested him when the ship arrived back in Penang and indicted him for manslaughter, but he was acquitted. Though the judge congratulated MacDuff on the verdict, the secretary to the government of Bombay later wrote that he was disappointed that he had not been convicted. ${ }^{84}$

The archives are peppered with the noise of the slaps, kicks, and threats that were dished out to convicts, routinely and with little contemporary comment ${ }^{85}-$ unless of course they provoked mutiny. The attempt to seize

76. Bombay Gazette, 6 July I84I.

77. Bengal Hurkaru, 23 May 1846.

78. IOR P/407/36 BomJP, i I October I 859: Advocate General's opinion, 27 September I 899.

79. Bengal Hurkaru, i4 September 1859 .

80. IOR P/407/36 BomJP, i I October I 859: Resolution of the Board, 3 October I 859 ; TNSA Madras Judicial Proceedings, I4 December I 860, nos I0I-I02: extract dispatch from HM's Secretary of State for India, 20 September I 860.

81. IOR P/407/36 BomJP, i I October I 859: Advocate General's opinion, 27 September I 859. 82. Clare Anderson, Legible Bodies: Race, Criminality and Colonialism in South Asia (Oxford, 2004), p. 39.

83. IOR P/I $42 / 9$ BJC, 27 November I 843 : deposition of Robert Cort, n.d.; IOR P/I $42 /$ I $_{2}$ BJC, 22 January I 844: deposition of Thomas Jones, 25 September I 843.

84. IOR P/I42/Is BJC, 29 April I844: C. Norris, Secretary to Government of Bombay, to Butterworth, 7 February I 844 .

85. IOR P/402/30 BomJC, 23 January I839: deposition of Rama Balloo, another convict, 25 December I838; IOR P/402/30 BomJC, 30 January I839: information of Pendygrass, I9 January I 839; Bombay Gazette, 30 July I 840. 
the Catherine, for example, took place after a convict called Kondajee Bapoo complained to the captain about his treatment. The captain slapped Kondajee around the face, and threatened him with a flogging. Another convict stated that later that evening Kondajee had resolved to murder him. ${ }^{86}$ One of the Virginia convicts, Hameer Rhadoo, claimed that before mutiny erupted Captain Whiffen had threatened to throw any man who was seasick overboard. Other convicts spoke of being kicked and thrown down by him. ${ }^{87}$

It is far from surprising then that convict mutineers mirrored this everyday brutality, and in this they were also intensely justice-seeking and mutinies were deeply performative. The Virginia convicts for example beat Captain Whiffen to a pulp. ${ }^{88}$ Those on the Clarissa gave a great collective shout when they fatally injured the captain. ${ }^{89}$ The symbolism of this physical anti-authoritarian violence ran deep. One convict informer (Freak) testified that the mutinous convicts tied up Captain Suffield, and when he asked for water told him he should have only two tin pots (the convicts' usual ration). They slit his throat, and threw him overboard, according to the informer saying "now this chain has been so many days on your legs is now on their's". ${ }^{\circ}$ Convicts also targeted ships' papers for destruction. They ripped up or burnt logbooks, indents, and convict rolls, in the hope that it would prevent their later identification. The Freak convicts were unwilling to take any chances, and because they were illiterate they threw overboard all the books and papers found in the captain's cabin..$^{91}$ The Clarissa convicts too ransacked the ship, and destroyed all its papers. ${ }^{92}$

After taking ships, convicts commonly removed their simple prison issue dhotis (waist cloths) and put on the clothes of the captain and his officers. This careful dressing up was supposed to present a façade of normality to passing ships. ${ }^{93}$ Yet it was also a visual expression of their newly acquired status and power. Convict leaders wore the captain's coat, sash, and sword; others took silk handkerchiefs and knotted them around their necks. Mutinies became carnivalesque, as convicts slaughtered livestock, made pilaf and curry, dissolved sugar into sherbet, drank and feasted. One of the first things the Clarissa convicts did after seizing the

86. IOR P/402/30 BomJC, 23 January I839: deposition of Rama Balloo; IOR P/402/30 BomJC, 30 January I 839 : information of Pendygrass.

87. Bombay Gazette, 30 July I 840 .

88. Ibid., 20 July 1840 .

89. Bengal Hurkaru, I 8 August I 854 .

90. IOR P/403/6 BomJC, 2 March I 842 : deposition of Michael Anthony.

91. IOR P/403/5 BomJC, I6 February I842: J.W. Salmond, Resident Councillor Penang, to Willoughby, is July i 84 I.

92. IOR P/I45/i 8 BJC, I3 September I 855 : Tickell to Bogle, 8 June I 854.

93. As claimed in the Bengal Hurkaru, 27 March I 848. 
ship was to make a drink by mixing some sugar that they found in the hold with seawater. ${ }^{94}$ Convicts drew their own lines of cultural distinction as they ate separately from those of other religions and castes, but all joined in dancing, singing, and making merry. ${ }^{95}$ Dressed in the garb of colonial authority to feast at the captain's table, these extraordinary scenes call out for our interpretation as the metaphorical capsizing of transportation ships, of the topsy-turvy world of the age of revolution.

And yet mutinous ships were not always radical or egalitarian spaces. First officer James Squire said the mutinous Clarissa convicts fought continually over rations. The Bengali convicts on board later testified that they had nothing to do with the mutiny; the Sikhs were responsible, they said, they had locked them below deck and appropriated most of the rations. When the ship ran aground, the Bengalis had been forced to work as porters. One of the recaptured Clarissa convicts Verream Singh stated in his defence: "I am a cultivator [...]. I never knew how to hold a musket how could I have fired one on board[?]." 6

\section{CONCLUSION}

A maritime focus on the age of revolution in the Indian Ocean necessarily incorporates subaltern perspectives, and suggests the importance of adding new layers of connection to the study of Europe, North America, and European colonies during the eighteenth and nineteenth centuries. My purpose here has been to unpack networks of empire, productivity, labour, and resistance in the Bay of Bengal and Indian Ocean, and in so doing to link together aspects of the age of rebellion across the region's rivers, seas, islands, littorals, and lands. Clearly, in the colonial context convict ships were both conduits for and sites of rebellion. They provided floating locales for mutiny and subversion; they were spaces in which peasants, pirates, and mutineers staged efforts to win freedom from a colonial nexus that linked punishment with voyaging and unfree labour; and they provided a means for the circulation of more generalized and ambitious forms of anti-colonial resistance and solidarity - as well as for the replication of established land-based forms of hierarchy.

There are important points of comparison here with a range of other contexts: with slave-ship mutinies and Australian convict piracy, with the downing of tools and petitioning of sailors and lascars, and with the libertarian, democratic, and "amok" desires and moments that frequently

94. IOR P/I45/18 BJC, I3 September I855: deposition of edoo serang.

95. IOR P/403/6 BJC, 2 March I 842: depositions of Michael Anthony, 7, 8 June I84I; Bombay Gazette, 20 July i 840.

96. IOR P/I45/1 8 BJC, I 3 September I 855 : deposition of convict Verream Sing, son of Joe Sing no. I05, 5 July I 854 . 
underpinned them all. Furthermore, proletarian and subaltern subversion moved around, and local struggles became generalized, within and across the very spaces that constituted "the age" of the age of revolution - that is, as a time of unfreedom, forced labour circulation, and exploitation. Mutiny, piracy, anti-colonialism, and proto-nationalism in the European, Atlantic, and Indian Ocean worlds: each reveals that we must necessarily bring into view the multiple connections between land and sea, and take a more expansive geographical approach to questions of resistance and revolution in the eighteenth and nineteenth centuries. 